\title{
A new autapomorphy of the taxon Tricoryptera and redescription of Ephemerythus
}

\section{Новая аутапоморфия таксона Triocoryptera и переописание Ephemerythus}

\author{
Nikita J. Kluge \\ Н.Ю. КАюге
}

\begin{abstract}
Department of Entomology, Saint-Petersburg State University, Universitetskaya nab. 7/9, Saint-Petersburg, 199034, Russia. E-mail: kluge@FK13889.spb.edu.

Кафедра энтомологии, биолого-почвенный факультет, С.-Петербургский государственный университет, Университетская наб. 7/9, С.-Петербург 199034, Россия.
\end{abstract}

KEY WORDS: Ephemeroptera, Tricorythidae, Tricoryptera, Ephemerythus, Ephemerythus niger ugandanus. КЛЮЧЕВЫЕ СЛОВА: Ephemeroptera, Tricorythidae, Tricoryptera, Ephemerythus, Ephemerythus niger ugandanus.

ABSTRACT. The taxon Tricoryptera Kluge, 2004 is characterized by unique ontogenesis of hind wing, that is an autapomorphy of this taxon; this character is expressed only in Ephemerythus/fg1 and some representatives of Leptohyphes/fg1, while in all other Tricoryptera hind wings are completely lost. System of Ephemerythus/fg1 is revised, the following subjective synonymy is suggested: Ephemerythus (= Tricomerella = Limnokijara syn.n.); Ephemerythus niger $(=E$. (Tricomerella) straeleni syn.n. $=E$. dissimillimus syn.n.). A new subspecies Ephemerythus niger ugandanus subsp.n. is described basing on imagoes reared from larvae in the west of Uganda.

РЕЗЮМЕ. Таксон Tricoryptera Kluge, 2004 характеризуется уникальным онтогенезом заднего крыла, что является его аутапоморфией. Этот признак выражен только у Ephemerythus/fg1 и у некоторых представителей Leptohyphes/fg1, тогда как у всех прочих Tricoryptera задние крылья полностью утрачены. Пересмотрена система Ephemerythus/fg1, предложена следующая субъективная синонимия: Ephemerythus (= Tricomerella; = Limnokijara syn.n.); Ephemerythus niger $(=E$. (Tricomerella) straeleni syn.n.; = E. dissimillimus syn.n.). По имаго, выведенным из личинок на западе Уганды, описан новый подвид Ephemerythus niger ugandanus subsp.n.

\section{Introduction}

In the monograph on mayfly systematics [Kluge, 2004] I gave revised diagnosis for the African taxon Ephemerythus/fg1 and all higher taxa to which it belongs. At that time, for no one species of Ephemerythus/ fg1, larvae and adults had been associated by rearing.
During collecting in Uganda in 2007, I was able to rear imagoes from larvae of one form, which is described here as a new subspecies Ephemerythus niger ugandanus subsp.n. The new material allows to make some additions to the diagnoses of Ephemerythus/fg1 and higher taxa.

All material examined (including the holotype of Ephemerythus niger ugandanus subsp.n.) is deposited in the Zoological institute of Russian Academy of Sciences (in Saint-Petersburg), temporarily locates in Department of Entomology of Saint-Petersburg State University.

In the lists of material examined, the following arbitrary signs are used: $\mathrm{L}$ - larva; $\mathrm{S}$ - subimago; I imago; L-S-I $\sigma^{\top}$ — male imago reared from larva; $\mathrm{L} / \mathrm{S} \mathrm{O}^{\top}$ male subimago extracted from mature larva.

\section{Systematic position of Tricoryptera}

The taxon Tricoryptera Kluge, 2004 belongs to the holophyletic taxon PANTRICORYTHI Kluge, 2004, which belongs to the holophyletic taxon Ephemerella/fg1, which belongs to the holophyletic taxon FuRCATERGALIAE Kluge, 1998, belonging to the holophyletic taxon BIDENTISETA Kluge, 1993 in the holophyletic taxon ANTERITORNA Kluge, 1993; holophyly of each of these taxa is proved by unique autapomorphies [Kluge, 2004].

However, some authors accept a taxon PANNOTA McCafferty \& Edmunds, 1979, which unites Ephemerella/fg1 with Caenotergaliae (originally — also with Posteritorna); this taxon has no place in phylogenetic systematics. Nobody suggested any diagnosis to Pannota: originally it was characterized only by fusion of larval fore protoptera, but in this respect Ephemerella/ fg1 has more similarity with Eusetisura (which was 
never attributed to Pannota), than with Caenotergaliae: in Ephemerella/fg1 and Eusetisura fore protoptera are connected by a mesial plate which can give raise to imaginal plumidia (Fig. 6), while in Caenotergaliae fore protoptera are connected only by scutellum [Kluge, 1997, 2004].

Detailed phylogenetic classification is given in the website "Phylogeny of Ephemeroptera" [Kluge, web publication].

\section{Characteristics of Tricoryptera}

The taxon Tricoryptera Kluge, 2004 is characterized by a unique autapomorphy: reduction of the proximal portion of $\mathrm{CuP}$ on fore wing, so that $\mathrm{CuP}$ lost its connection with $\mathrm{CuA}$ [Kluge, 1997, 2004].

Another autapomorphy, known for Tricoryptera, is reduction of hind wings: in all representatives hind wing is either diminished, with elongate costal projection, or completely lost. This character was regarded to be nonunique, because diminishing and loss of hind wing independently occurs in various non-related mayfly taxa; in many cases diminishing of hind wing is accompanied with elongation of its costal projection. But actually, as it is shown below, modification of hind wing in Tricoryptera has unique features, not found in any other mayflies; so this character represents the second good autapomorphy, which proves holophyly of Tricoryptera.

Besides these two autapomorphies, Tricoryptera have the following characters of unclear phylogenetic status:

Infrascutellum is reduced, and sculellum is enlarged and modified; this character is in common with Teloganodes/fg1 (which, probably, is a sister group with Tricoryptera) and with Caenoptera (which has non-explainable similarity with Tricoryptera [Kluge, 1997, 2004]).

Subimaginal cuticle of mesonotum has no relief line separating lateral pigmented area from medial colorless area; this line is initially characteristic for Ephemerella/ fg1 [Kluge, 2004]; it is well expressed in all Ephemerella/fg2, Vietnamella/fg1 and some other taxa, but is absent in all Tricoryptera. Formerly, I had no subimagoes of Ephemerythus/fg1, so structure of their subimaginal mesonotum was unknown. The newly examined specimens of Ephemerythus niger from Uganda have no this line (Fig. 20), and this allows to conclude that the line is absent in all Tricoryptera. Among Ephemerella/fg1, this line is absent, besides Tricoryptera, also in Teloganodes/fg1.

Tricoryptera also have non-unique characters common with Teloganodes/fg1 and some other taxa: absence of paired submedian projections on larval abdominal terga, which are characteristic for many other Ephemerella/fg1; loss of stick-like tergalii I; reduction of tergalii VII.

In the previous diagnosis of Tricoryptera, I gave also one more non-unique character: "adults are shortlymolting..." [Kluge, 2004]. Actually, this character is wrong, because shortly-molting adults are characteristic not for all Tricoryptera, but only for a part of them.
As I could observe in Uganda, subimagoes of Ephemerythus niger and Dicercomyzon costale Kimmins, 1957 develop for a rather long time; unlike Tricorygnatha and Leptohyphes/fg1, whose subimagoes and imagoes keep wings spread by sides, like Caenoptera, subimagoes of Ephemerythus/fg1 and Dicercomyzon/fg1 keep their wings raised up, as in most other Ephemeroptera.

\section{Autapomorphy of Tricoryptera - unique modification of hind wing}

Hind wing is diminished and has a long, narrow, pointed costal projection; at the same time, larval hind protopteron has no costal projection, but retains a shallowly rounded convexity on costal margin; when adult hind wing develops inside protopteron, its costal projection locates inside the costal convexity of protopteron, being arched at apical direction (Figs 3 and 9). Such hind wings are present in Ephemerythus/fg1 (which belongs to Tricoryptera-Afrotricorythi), Leptohyphes/ fg2 and some other taxa belonging to TricorypteraLetohyphes/fg1. Shape of hind protoptera in these taxa is similar, but shape of adult hind wing is different: in Ephemerythus/fg1 costal projection is directed anteriorly, can be straight [Gillies, 1960: Fig. 2; Kluge, 2004: Fig. 99C] or somewhat arched apically (Fig. 2); in representatives of Leptohyphes/fg1, the costal projection is arched proximally (Fig. 8). In other Tricoryptera hind wings and their larval protoptera are completely lost, so this character is not expressed.

By structure and development of hind wing, the taxon Tricoryptera differs from most Ephemeroptera and most insects in general, whose adult wings and protoptera have similar shape and retain evolutionary correlation. Similarly diminished hind wing with enlarged costal projection occurs in many non-related mayfly taxa (particularly, in Teloganodes/fg1, some other Ephemerella/fg1 and in many representatives of Leptophlebia/fg1), but in these cases larval hind protopteron has a costal projection, whose apex corresponds to the apex of costal projection of adult hind wing.

\section{Old-World Tricoryptera}

As shown earlier [Kluge, 2004], all Old-World representatives of Tricoryptera constitute a holophyletic taxon AFrOTRICORYTHI Kluge, 2004, which is characterized by a unique Y-shaped vein in cubital field (Fig. 1) and is divided into 4 distinctly outlined holophyletic taxa: Ephemerythus/fg1, Dicercomyzon/fg1, Machadorythus/fg1 and Tricorygnatha. Characteristic and composition of the taxon Ephemerythus/fg1 are discussed below.

\section{Additions to the general characteristic of Ephemerythus/fg1}

To the characteristic of Ephemerythus/fg1 given earlier [Kluge, 2004], the following additions and comments should be given. 
In imago and subimago all claws, including claws of male imaginal fore leg, are ephemeropteroid (that is a plesiomorphy [Kluge, 2004]). In the original description [Gillies, 1960], there was stated that "Male fore leg,
... claws similar; mid and hind legs, ... claws dissimilar." This is a mistake. M.T. Gillies sent me paratypes of E. kiboensis (one of the three species described by him in 1960) - 4 male imagoes collected by him on Kili-

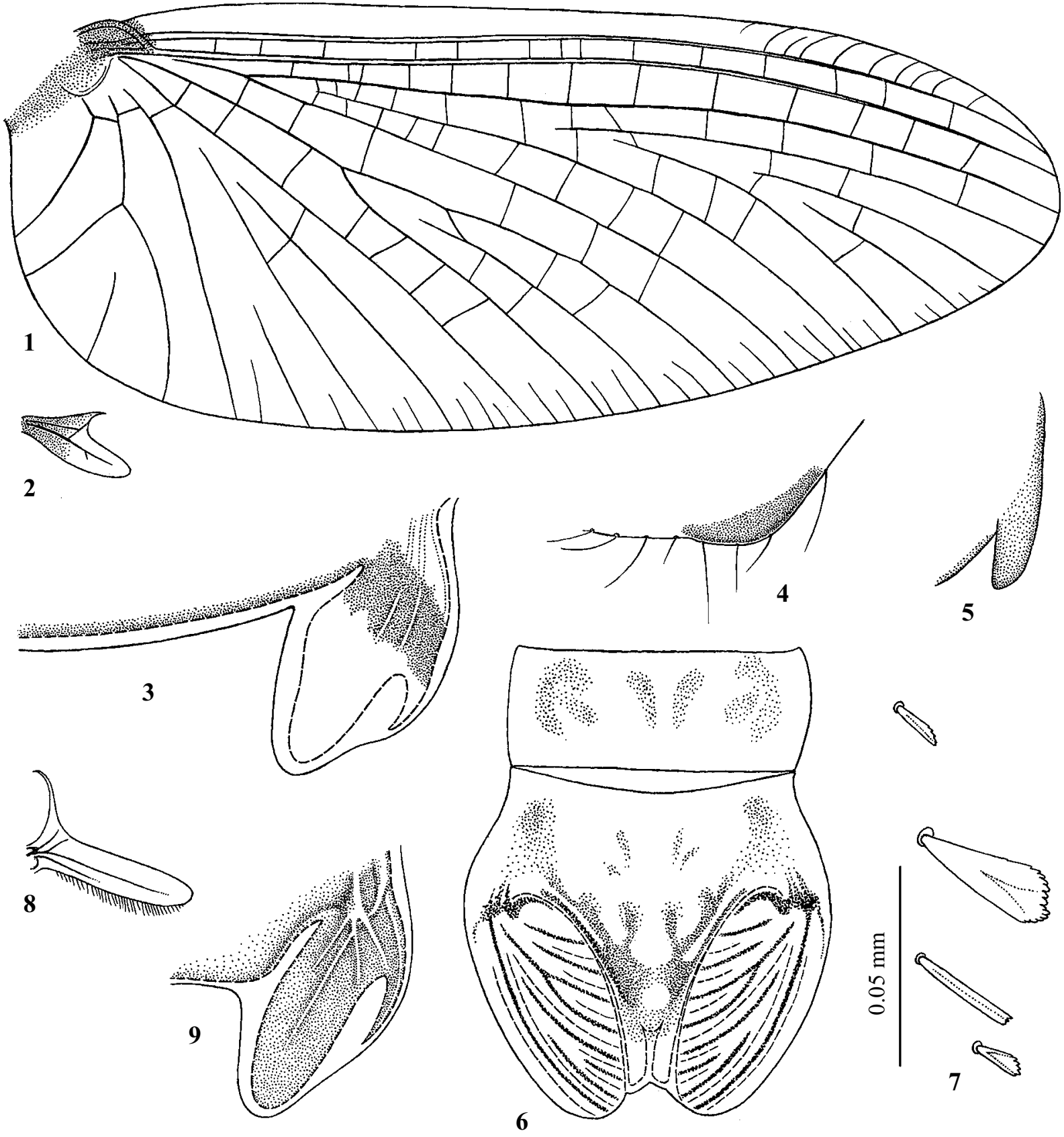

Figs 1-9. 1-7 - Ephemerythus niger ugandanus subsp.n.; 8-9 - Leptohyphes zalope; 1-2 - fore and hind wings of male imago at the same scale; 3 - hind protopteron of last instar male larva, with hypoderm shown by interrupted line; 4 - hind protopteron of last instar female larva; 5 - hind wing of female imago (Figs 3-5 at the same scale); 6 - larval pronotum and mesonotum (outlines of hypodermal rudiments of wings and plumidia shown by interrupted line; hypodermal pigmentation shown by dots; cuticular pigmentation not shown); 7 - setae on mesonotum with scale bar; 8 - hind wing of male imago; 9 - hind protopteron of last instar male larva, with hypoderm shown by interrupted line [8 and 9 from Kluge, 2004].

Рис. 1-9. 1-7 - Ephemerythus niger ugandanus subsp.n.; 8-9 - Leptohyphes zalope; 1-2 - переднее и заднее крылья самца имаго в одном масштабе; 3 - задний протоптерон личинки самца последнего возраста, гиподерма показана прерывистой линией; 4 - задний протоптерон личинки самки последнего возраста; 5 - заднее крыло самки имаго (рисунки 3-5 в одном масштабе); 6 - пронотум и мезонотум личинки (очертания гиподермальных зачатков крыльев и плюмидий показаны прерывистой линией; гиподермальная пигментация показана пунктировкой; кутикулярная пигментация не показана); 7 - щетинки на мезонотуме; 8 - заднее крыло самца имаго; 9 - задний протоптерон личинки самца последнего возраста, гиподерма показана прерывистой линтией [8 и 9 из Kluge, 2004]. 
manjaro 13.X.1958. One of these specimens has a fore leg, and its claws are dissimilar (i.e., ephemeropteroid). All representatives of $E$. niger (the type species of Ephemerythus), collected by me in Uganda, also have all claws ephemeropteroid.

Larvae are operculate-gilled: anteriormost pair of tergalii (belonging to abdominal segment II), serve as gill opercula, and other tergalii (pairs III-VI) serve as tracheal gills. While morphologically tergalii II only slightly differ from the next ones (Figs 10-14), they strongly differ in their movement. As I could observe in Uganda, when larva of Ephemerythus niger makes respiratory movements, its tergalii II only raise up to allow other tergalii to move, but are unable to make rhythmical respiratory movements themselves. Tergalii of the next pairs make fast rhythmical respiratory movements and provide water current necessary for respiration. By this feature Ephemerythus/fg1 well differs from Tricorygnatha, whose tergalii of all pairs are able to make synchronous, rhythmical, respiratory movements. The same kind of tergalial movements, as in Ephemerythus/ fg1, independently evolved in Leptohyphes/fg1, Caenotergaliae and some other taxa.

In male larva, caudalii (cerci and paracercus) are thickened in proximal part, unlike caudalii of female, which have usual form. The same in Tricorygnatha, Leptohyphes/fg1 and Caenoptera, unlike Machadorythus/fg1 and Dicercomyzon/fg1. This character was not mentioned in the previous publication [Kluge, 2004], because at that time I did not see male larvae.

\section{Composition and classification of Ephemerythus/fg1}

Originally [Gillies, 1960] the taxon Ephemerythus/ fg1 was described as a subfamily Ephemerythinae Gillies, 1960 with a single genus Ephemerythus Gillies, 1960 and 3 species from Tanganyika: E. niger Gillies, 1960 (the type species), E. pictus Gillies 1960 and $E$. kiboensis Gillies, 1960. All three species were described as imagoes. Larvae were described only for the genus Ephemerythus in general, being not associated with any concrete species.

G. Demoulin [1964] established a new subgenus Tricomerella Demoulin, 1964 for one species Ephemerythus (Tricomerella) straeleni Demoulin, 1964, described by him from Congo as larva with extracted female subimaginal parts. In another paper [Demoulin, 1965] he described larvae of two species of Ephemerythus from Tanganyika, presumably determined by him as "E. ?kiboensis" and "E. ?pictus". This author did not give explanation, why he regarded Ephemerythus (Tricomerella) straeleni, characterized by larval structure, to be different from Ephemerythus (Ephemerythus) niger, which was known only by imaginal structure.

J.-P. Kopelke [Kopelke, 1980, 1981] described a new species Ephemerythus dissimillimus Kopelke 1980 from Zaire, basing on imagoes and eggs; according to this description, E. dissimillimus differs from $E$. niger and other species described by M.T. Gillies, by dissimilar claws of male imaginal fore leg. Actually, this difference does not exist (see above).

L. Jacobus and P. McCafferty [2006] examined subimaginal parts and eggs extracted from mature larvae and discovered, that the larvae described as Ephemerythus (Tricomerella) straeleni (the type species of Tricomerella), imagoes described as E. niger (the type species of Ephemerythus) and eggs described for $E$. dissimillimus belong to closely related species; because of this, they suggested synonymy of Ephemerythus and Tricomerella. This conclusion is proven by a new material - adults reared from larvae in Uganda in 2007; it also reveals, that all three species names, E. niger, $E$. (Tricomerella) straeleni and E. dissimillimus, belong to the same species (see below).

In the same paper Jacobus and McCafferty established a new genus Limnokijara Jacobus et McCafferty, 2006, which includes L. kiboensis (Gillies, 1960) (the type species) and L. pictus (Gillies, 1960). As the generic characters of Limnokijara, they listed the following ones: (1) "maxilla with reduced apical spines and spinous processes" (that actually means that proximal dentiseta is plesiomorphically non-enlarged ); (2) "lamellate gills on abdominal segments $2-5$ only" (that means that tergalii VI are lost); (3) hind wings always present, larger than in Ephemerythus and not colored; (4) "prominent spinelike setae distally on the inner margin of genital forceps segment I'. Actually the first two characters belong to larvae, while larvae of the both species attributed to Limnokijara are unknown. Demoulin [1965] only presumably associated larvae of two species with E. kiboensis and E. pictus; these larvae have maxillae as ascribed to Limnokijara, but nothing is known about their tergalii. A larva from Cameroon, which I received from M.T. Gillies, has proximal dentiseta enlarged (as in the type species of Ephemerythus), while tergalii VI are absent (as is ascribed to Limnokijara). The third character, ascribed to Limnokijara, is wrong, because at least in males of $E$. niger (the type species of Ephemerythus) and E. kiboensis (the type species of Limnokijara), which were examined by me, hind wings have the same size; nothing is said about difference of their size in literature; according to the original description [Gillies, 1960], in E. pictus "hind wing brownish-purple to base of spur". The fourth character is also wrong: according to the original description [Gillies, 1960], in E. kiboensis "basal segment with numerous sharp spines on inner surface extending almost to its base"; in specimens received by me from M.T. Gillies, they are really not concentrated distally (Fig. 27), being similar to that of E. niger (Fig. 25). So the "genus Limnokijara" has no any characteristics and should be regarded as a junior synonym of Ephemerythus (= Limnokijara syn.n.).

At the present time only 3 species of Ephemerythus/fg 1 are described: $E$. niger $[=E$. $($ Tricomerella $)$ straeleni $;=E$. dissimillimus], E. pictus and E. kiboensis. However, among larvae, on which originally [Gillies, 1960] the generic diagnosis of Ephemerythus was based, there were repre- 


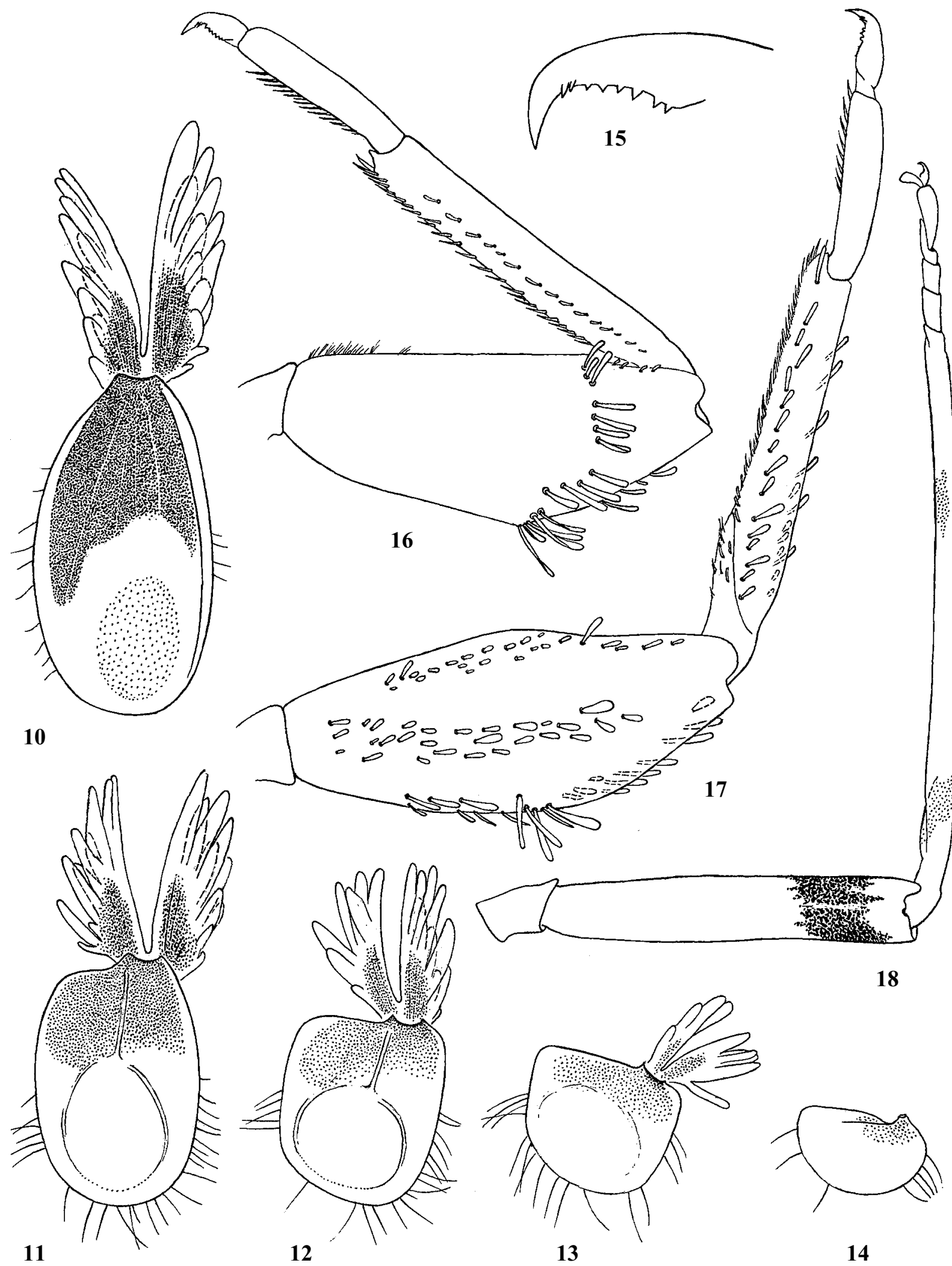

Figs 10-18. Ephemerythus niger ugandanus subsp.n.: 10-17 - larva: 10-14 - tergalii II-VI with ventral portions turned out; 15 claw; 16-1 7 - fore and middle legs, dorsal view; 18 - middle leg of male imago.

Рис. 10-18. Ephemerythus niger ugandanus subsp.n.: 10-17 - личинка: 10-14 - тергалии II-VI пар с отогнутой вентральной долей; 15 - коготок; 16-1 7 - передняя и средняя ноги, дорсально; $18-$ средняя нога самца имаго. 
sentatives of different species. He sent me two larvae, one from Tanzania, another from Cameroon, which belong to two different species, and the both are not conspecific neither with $E$. niger, nor with larva ascribed by Demoulin [1965] to E. pictus. This means that there are more than three species of Ephemerythus, and at least one of them is not described (Table 1).

\section{Ephemerythus niger Gillies, 1960}

= Ephemerythus (Tricomerella) straeleni Demoulin 1964, syn.n. = Ephemerythus dissimillimus Kopelke 1980, syn.n.

Larva is described by Demoulin [1964]. Male and female imagoes are described by Gillies [1960] and Kopelke [1981]. Egg is described by Kopelke [1980]. Distributed in central and eastern Africa: Congo, Tanganyika, west of Uganda. The form which inhabits in Uganda, is described below as a new subspecies Ephemerythus niger ugandanus subsp.n.

\section{Ephemerythus niger ugandanus Kluge, subsp.n.} Figs 1-26

MATERIAL. Holotype: L-S-IO' $\{$ specimen [XXXIII] (4B)\}: UGANDA, Kasese district, river Nyamagasan, Kiburara, 813.VIII.2007, coll. N. Kluge. Paratypes: the same locality as holotype, $1 \mathrm{~L}-\mathrm{SO}^{\top}, 21$ larvae; UGANDA, Kanungu district: river Munyaga near camping of Bwindi National Park, 21-25.VII.2007, coll. N. Kluge: 1 L-S-I $+, 6 \mathrm{~L}-\mathrm{S}+, 2 \mathrm{~L} / \mathrm{SO}^{7}, 2 \mathrm{~L} / \mathrm{S}$ \%, 14 larvae. River Ishasha below Bwindi National Park, 14.VII.2007, coll. N. Kluge: 1 L/SO', 3 larvae.

Larva. CUTICULAR COLORATION: Whole cuticle light-brownish, nearly unicolor or with indistinct diffusive maculae only.

HYPODERMAL COLORATION: Head and thorax have blackish maculae, variable individually. Each femur has blackish band near apex. Fore protoptera have blackish bases and often (not always) have blackish lines corresponding to convex longitudinal veins; their invisible ventral sides often have blackish lines corresponding to concave longitudinal veins (Fig. 6). Abdomen has blackish maculation as in imago, with the same sexual dimorphism: terga I-II and VII-VIII in most

Table 1. Characters of the known forms belonging to the taxon Ephemerythus/fg1. Таблица 1. Признаки изученных представителей Ephemerythus/fg1.

\begin{tabular}{|c|c|c|c|c|c|c|c|c|}
\hline & 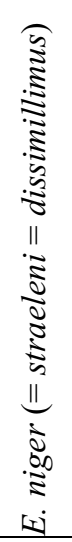 & 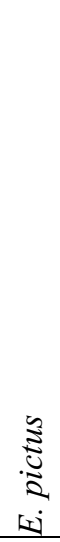 & 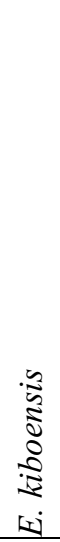 & 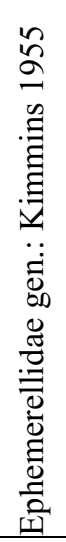 & 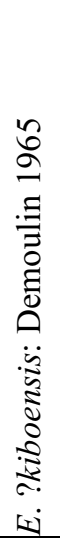 & 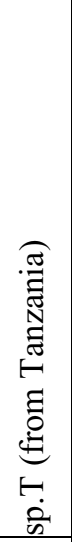 & 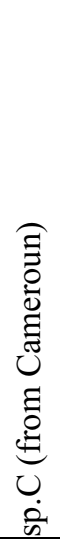 & 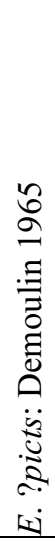 \\
\hline \multicolumn{9}{|l|}{ Larva: } \\
\hline proximal dentiseta enlarged & + & $?$ & $?$ & - & - & - & + & - \\
\hline pronotum with stretched posterolateral corners & - & $?$ & $?$ & - & - & - & - & + \\
\hline hypoderm of fore protoptera: membrane dark & - & $?$ & $?$ & + & $?$ & + & $?$ & $?$ \\
\hline hypoderm of fore protoptera: veins dark & + & $?$ & $?$ & $?$ & $?$ & - & $?$ & $?$ \\
\hline transverse setal row on fore femur regular & - & $?$ & $?$ & + & + & + & - & - \\
\hline homolog of transverse setal row on mid \& hind femur & + & $?$ & $?$ & - & - & - & - & + \\
\hline tergalius $\mathrm{V}$ with ventral lobe & + & $?$ & $?$ & $?$ & $?$ & - & - & $?$ \\
\hline tergalius VI present & + & $?$ & $?$ & - & $?$ & - & - & $?$ \\
\hline \multicolumn{9}{|l|}{ Imago: } \\
\hline hind wing proximally dark & + & + & - & $?$ & $?$ & + & $?$ & $?$ \\
\hline female hind wings & \pm & + & + & $?$ & $?$ & + & - & $?$ \\
\hline male abdominal terga III-V light & + & + & - & $?$ & $?$ & $?$ & $?$ & $?$ \\
\hline male abdominal tergum VI light & + & - & - & $?$ & $?$ & $?$ & $?$ & $?$ \\
\hline 1st segment of gonostylus with spines on distal swelling only & - & + & - & $?$ & $?$ & $?$ & $?$ & $?$ \\
\hline penes angulate & + & - & - & $?$ & $?$ & $?$ & $?$ & $?$ \\
\hline \multicolumn{9}{|l|}{ Egg: } \\
\hline with caudal tube & + & $?$ & $?$ & $?$ & $?$ & + & $?$ & $?$ \\
\hline
\end{tabular}

+ - present, - - absent, ? - undefined.

+ - есть, - - нет, ? - не известно 
part dark, tergum IX in most part light; in male terga III-VI in most part light (Fig. 19), in female much darker. Dorsal lamella of tergalius II (gill operculum) has hypoderm blackish in proximal half, colorless in distal half (Fig. 10). Dorsal lamellae of tergalii III-VI and ventral lamellae of tergalii II$\mathrm{V}$ are diffusively darkened in proximal part (Figs 11-14). In proximal part of caudalii hypoderm of each segment is black- ish distally and colorless proximally; in distal parts of caudalii hypoderm is colorless.

SHAPE AND SETATION: As figured by Demoulin [1964: Fig.1A-I]. Maxilla lacks palp; proximal dentiseta is enlarged, both dentisetae are pectinate; besides dentisetae, biting edge bears a few (about 5-7) large setae (Fig. 24). Pronotum is nearly rectangular, with fore and hind margins nearly straight,

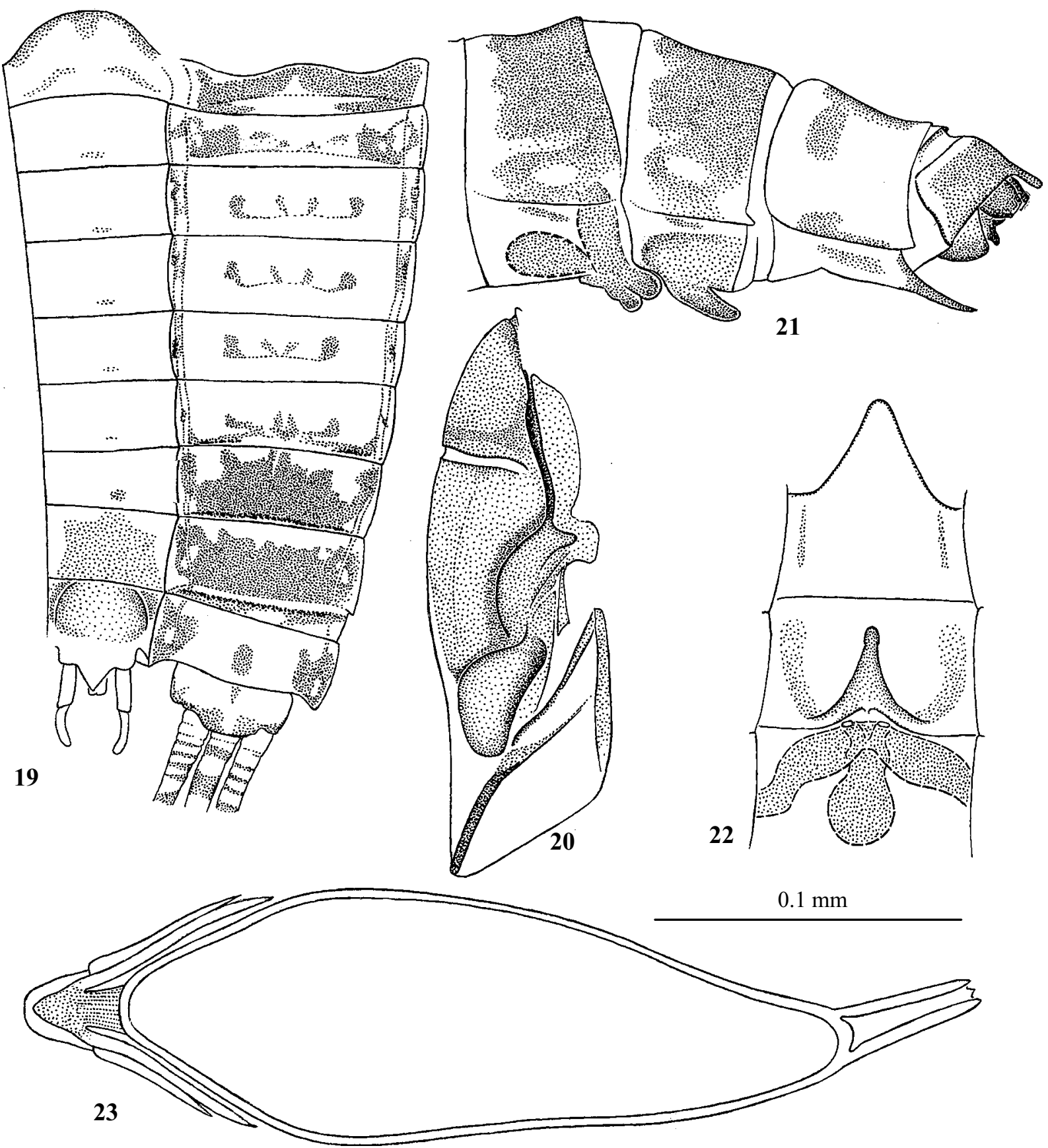

Figs 19-23. Ephemerythus niger ugandanus subsp.n.: 19 - abdomen of male imago, spread on slide (hypodermal pigmentation shown by dots); 20 - subimaginal exuviae of right half of mesonotum (cuticular pigmentation shown by dots); 21 - abdominal segments VII-X of female imago, lateral view (hypodermal pigmentation shown by dots, internal genitals shown by interrupted line); 22 - the same, ventral view; 23 - optic section of egg with scale bar; 19-20 - holotype.

Рис. 19-23. Ephemerythus niger ugandanus subsp.n.: 19 - брюшко самца имаго, расправленное на препарате (гиподермальная пигментация показана пунктировкой); 20 - субимагинальтный экзувий правой половины мезонотума (кутикулярная пигментация показана пунктировкой); 21 - VII-X сегменты брюшка самки имаго, латарально (гиподермальная пигментация показана пунктировкой, внутренние гениталии показаны прерывистой линией); 22 - то же , вентрально; 23 - оптический срез яйца; 19-20 - голотип. 
lateral margins slightly convex (Fig. 6). Mesial plate of mesonotum [characteristic for Ephemerella/fg1 — see Kluge, $2004]$ nearly reaches apices of fore protoptera; in course of transformation to subimago, most its hypoderm degenerate and does not give rise to imaginal plumidia (see below). Pronotum and mesonotum, including mesial plate, bear small spatulate setae of variable size and proportions (Fig. 7); fore protoptera lack such setae, bear long hair-like setae. Fore legs are the shortest, hind legs the longest. Femora bear large, stout, spatulate, brown setae of variable length and width, arranged as the following: On fore femur, instead of a regular rows characteristic for Pantricorythi [Kluge, 2004], there is a transverse oblique stripe of irregularly situated, long, spatulate setae of variable size; longitudinal row on distal part of outer margin is either absent, or consists of a few irregularly situated, spatulate setae (Fig. 16). On middle and hind legs there are 3 longitudinal stripes of irregularly situated, spatulate setae: (1) a longitudinal stripe of small setae on anterior side near inner margin; (2) a longitudinal stripe of longer setae along middle of anterior side and (3) a longitudinal stripe of long setae on outer margin; at the middle of outer margin this stripe forms a short transverse row, serially homologous to the transverse row on fore femur (Fig. 17). Tibiae bear irregularly situated, pointed, stout, spine-like setae on inner margin and have spatulate setae arranged as the following: on fore tibia one row of small spatulate setae on anterior side (Fig. 16), on middle and hind tibia 2 rows of larger spatulate setae (Fig. 17). Each tarsus bears a row of stout, pointed, spine-like setae on inner margin, lacks spatulate setae. Each claw has 5-7 denticles on inner side and 1-3 subapical denticles on anterior side (Fig. 15). Abdominal segments II-VI lack posterolateral spines; segments VIIIX have posterolateral spines, which become longer from segment VII to segment IX. Posterior margins of abdominal terga are smooth or with fine serration, bear long, thin setae. Sternum IX of male is similar to that of female, protogonostyli are not expressed; protopenis as in Fig. 26. Bases of tergalii II$\mathrm{V}$ are adjacent to posterior margins of terga; bases of tergalii VI are small and separated from posterior margin of tergum. Tergalii II are operculate, unable for respiratory vibrations; their ventral bifurcate lobes are well-developed and have numerous processes. Tergalii III-V also with well-developed ventral bifurcate lobes with numerous processes. Tergalii VI are short, without ventral lobes. Tergalii VII are absent. Caudalii of male are thickened in proximal parts. Each segment of caudalii bears a whorl of long, stout, setae on distal margin; on inner sides of cerci and lateral sides of paracercus these setae are slightly longer, forming secondary swimming setation.

Subimago. CUTICULAR COLORATIONANDTEXTURE: Cuticle of mesonotum is light brown, with contrasting, transverse, colorless stripe on mesonotal suture (Fig. 20); Microtrichiae densely cover all areas of mesonotum except for posterior scutal protuberances; cuticle of posterior scutal protuberances lacks microtrichiae, has net-like relief. Cuticle of thoracic sterna and pleura in most part is colorless, superior pleural suture is brown, lateropostnotal sclerites are light brownish. Cuticle of legs, abdomen and caudalii is colorless. Wings are light, pale grayish (basally with internal blackish markings as in imago).

HYPIDERMAL COLORATION: As in imago.

SHAPE: In male subimago, genitals are similar to that of imago. In female subimago, subanal plate is as long as in imago, but lacks secondary ovipositor: sterna VII and VIII are flat, with straight margins; future imaginal ovipositor is visible through colorless cuticle only as color pattern (Fig. 22).

Imago, male. Eyes are nearly as small as in female, widely separated. Head and prothorax ocher, with blackish hypodermal maculation. Pterothorax has light brown cuticular pigmen- tation on notum, episternum, furcasternum, postnotum and lateropstnotum of mesothorax, notum and episternum of metathorax. Membranous areas of pterothorax have blackish hypodermal maculation. Plumidia are short or absent (in spite of long mesial plate of larva - see above). Fore leg is ocher, femur has irregular blackish maculation all over its length, with blackish band near apex. Middle and hind legs are ocher, femur with blackish band near apex, tibia indistinctly tinged with gray near patella-tibial suture and at apical part (Fig. 18). Fore wing is colorless, base blackish, veins yellowish (Fig. 1). Hind wing (see autapomorphy of Tricoryptera above) in proximal half is blackish, in distal half colorless (Fig. 2). Abdomen is hyaline, with contrasting blackish maculae: terga I-II in most part blackish; terga III-VI in most part colorless, with small paired grayish maculae; terga VII-VIII in most part blackish; tergum IX in most part colorless, with blackish median spot and blackish lateral margins; tergum $\mathrm{X}$ light, with blackish margins; sternum I has indistinct grayish maculae; sterna IIVII are colorless, each with indistinct unpaired grayish macula near hind margin; sterna VIII-IX in most part are grayish (Fig. 19). On sternum IX, lines of proximal attachment of sternostyligeral muscles are widely separated, semicircular; sternostyligeral muscles are paired, with proximal bases widely separated (Fig. 25). Styliger has a triangular, median projection. Penis has angulate lateral margins. Styliger, penis and gonostyli are light. Caudalii have each segment colorless in proximal half and blackish in distal half.

Imago, female. Head and thorax are similar to that of male. Legs are darker, dirty ocher-brownish, each femur has a blackish band near apex. Fore wing is slightly tinged with brownish, especially in costal and subcostal fields. Vestige of hind wing is either absent, or has a form of a very small (about $0.1 \mathrm{~mm}$ length) papilla (Fig. 5). Abdomen is ocher; blackish maculae on terga I-II and VII-VIII are as in male; terga III-VI has blackish maculae a little smaller than on tergum VII; each sternum has a pair of longitudinal, lateral stripes. Secondary ovipositor consists of a short papilla on posterior margin of sternum VII and a longer narrow process arising in posterior direction from anterior margin of sternum VIII (Figs 21-22); cuticle of these formations is colorless, hypoderm blackish. Subanal plate of sternum IX is long and narrowly-triangular.

Egg. Described by Kopelke [1980]. Shape is unusual, long, narrowing toward pole opposite to the cap (Fig. 23). Cap has composite structure, with two layers and additional small cap on apex. Chorion is smooth. The pole opposite to the cap, bears an unusual tube, which terminates by opening surrounded by denticles; this tube bears adhesive threads.

Dimensions. Fore wing length 6-7 $\mathrm{mm}$.

Comparison. The new subspecies differs by the following characters of female: hind wing of female is always absent, and fore wing of female imago is slightly tinged by brownish. According to the original description of E. niger, its female has "hind wings as in male; sometimes reduced or absent" and "fore wing hyaline except at wing root". According to the description of $E$. straeleni, the single known female specimen has "les ailes II ont un calus costal allongé en éperon triangulare". According to the description of E. dissimillimus, its "Hinterflügel zu einem winzigen, $0.2 \mathrm{~mm}$ langen Stummel reduziert" and "Vorderflügel hyalin".

\section{Ephemerythus kiboensis Gillies, 1960}

MATERIAL. TANZANIA, Kilimanjaro, Marangu, 13.X.1958, coll. M.T. Gillies ( Q189-191): $4 \mathrm{O}^{7}$ imagoes.

Imago, male. Described by Gillies [1960]. Claws of fore leg are ephemeropteroid (in contrast to the original description - see discussion above). Genitals as in Fig. 27. 
Ephemerythus sp.T 1956.

? "nymph of Ephemerellidae (genus uncertain)": Kimmins,

?= "Ephemerythus ? kiboensis": Demoulin, 1965

MATERIAL. TANZANIA, Tanganyika Territory, Amani, Dod-

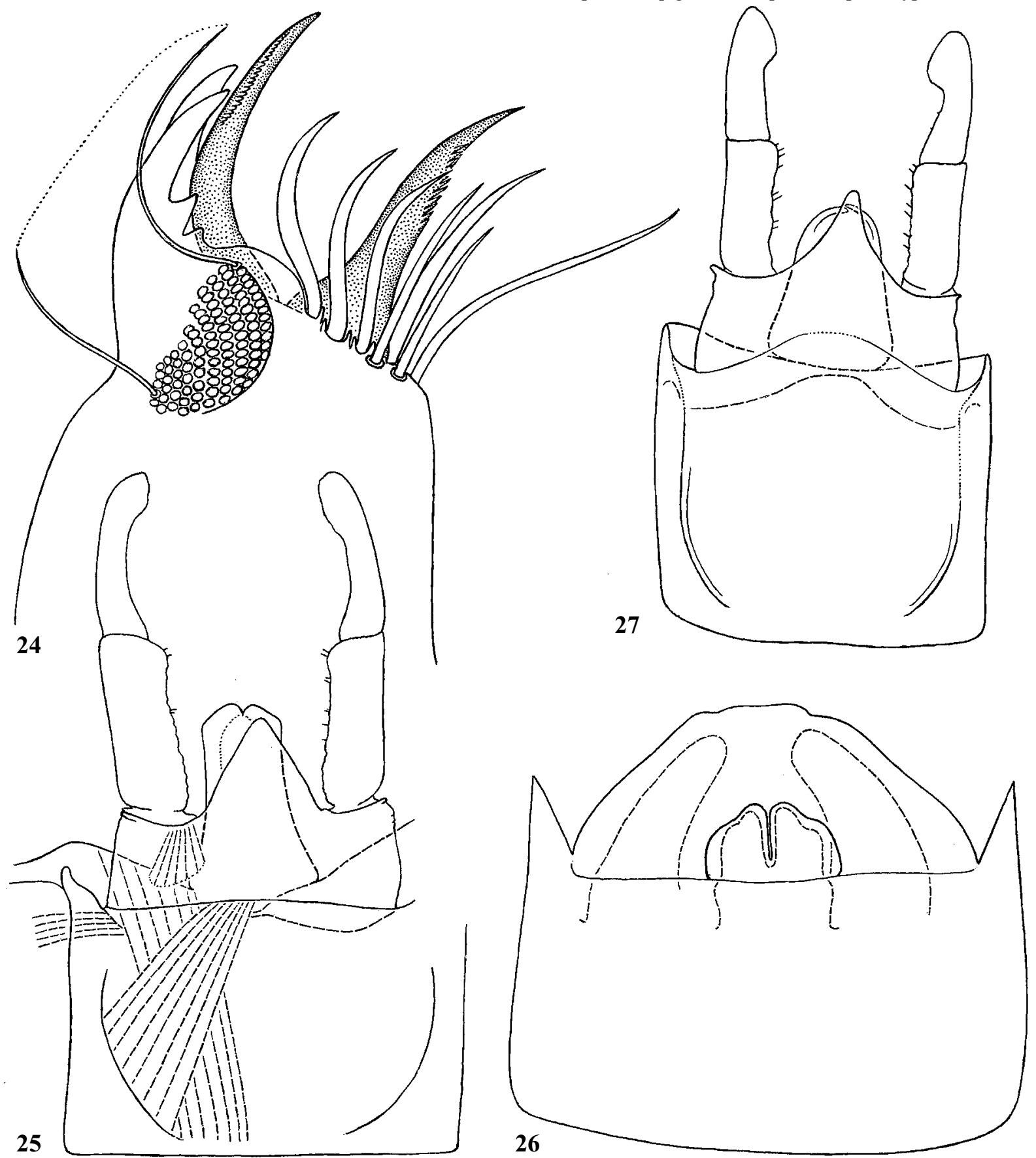

we, 5.VI.1961, coll. M.T. Gillies: 1 t larva. light-brownish, nearly unicolor or with indistinct diffusive maculae only.

HYPODERMAL COLORATION: All legs are gray in distal part, non-pigmented in proximal part. Hypoderm of fore
Larva. CUTICULAR COLORATION: Whole cuticle is

Figs 24-27. 24-26 - Ephemerythus niger ugandanus subsp.n., 27 - E. kiboensis; 24 - apex of maxilla, ventral view (dentisetae shown by dots; most part of apical setae not shown, area occupied by them shown by dotted line); 25 - genitals of male imago, holotype, ventral view (musculature of left half shown by interrupted lines); 26 - abdominal sternum XI of male larva, dorsal view (hypodermal rudiments of future subimaginal penis and gonostyli shown by interrupted lines). 27 - genitals of male imago, ventral view.

Рис. 24-27. 24-26 - Ephemerythus niger ugandanus subsp.n.; 27 - E. kiboensis; 24 — вершина максиллы, вентрально (дентисеты показаны пунктировкой; большая часть апикальных щетинок не показана, занимаемая ими область показана точечной линией); 25 — гениталии самца имаго, голотип, вентрально (мускулатура левой половины показана прерывистыми линиями); 26 - XI стернит брюшка личинки самца, дорсально (гиподермальные зачатки будущего субимагинального пениса и гоностилей показаны прерывистыми линиями); 27 - гениталии самца имаго, вентрально 
wing membrane is uniformly dark brown, veins light. Hypoderm of hind wing membrane is brown, darker in proximal half.

SHAPE AND SETATION: Maxilla has biting edge not shortened, proximal dentiseta is not enlarged, ventral row of setae is not shortened [as in Demoulin, 1965: Fig. 11f]. Femora are wide, with stout spatulate setae arranged typically for Pantricorythi: on fore femur a regular transverse row near middle is continued distally on outer and inner margins; on middle and hind legs rows run along whole outer and inner margins. Hind protoptera are developed, their shape is similar to male hind protoptera of E. niger (Fig. 3). Abdominal segments I-V lack posterolateral spines, segments VI-IX have posterolateral spines. Bases of tergalii II-IV are adjacent to posterior margins of terga; bases of tergalii $\mathrm{V}$ are small and separated from posterior margin of tergum. Tergalii V lack ventral portion; tergalii VI are absent.

Comparison. This larva differs from $E$. niger by nonenlarged proximal dentiseta and reduction of hind pairs of tergalii. Possibly it is conspecific with larvae described by Demoulin [1965] as "E. ?kiboensis". Relation with E. kiboensis and E. pictus is unknown. Possibly, this larva belongs to the same species which was described and figured by Kimmins [1955] as "nymph of Ephemerellidae (genus uncertain)".

\section{Ephemerythus sp.C}

MATERIAL. Cameroon, Yaoundé, 6.IX.1956, coll. M.T. Gillies: 1 larva.

Larva. CUTICULAR COLORATION: Whole cuticle is light-brownish, nearly unicolor or with indistinct diffusive maculae only.

SHAPE AND SETATION: Maxilla has biting edge shortened and directed apically, with proximal dentiseta strongly enlarged and ventral row of setae shortened (similar to Fig. 24). Hind protoptera are absent. Abdominal segments I-V lack posterolateral spines; segments VI-IX have posterolateral spines. Bases of tergalii II-IV are adjacent to posterior margins of terga; bases of tergalii $\mathrm{V}$ are small and separated from posterior margin of tergum. Tergalii $\mathrm{V}$ lack ventral portion; tergalii VI are absent.

Comparison. This larva differs from $E$. niger by reduction of hind pairs of tergalii. Its relation with E. kiboensis and E. pictus is unknown.
ACKNOWLEDGEMENT. This investigation was supported by the Russian federal program for support leading scientific schools, grant No. 963.2008.4.

\section{References}

Demoulin G. 1964. Ephemeroptera // Parc National de l'Upemba. Mission G.F. de Witte. T.68. No.2. P.13-27.

Demoulin G. 1965. LXXXVIII. Ephemeroptera// Mission zoologique de 1'I.R.S.A.C. en Afrique orientale (P. Basilewsky et N. Leleup, 1957) // Annales du Musée Royal d'Afrique Centrale, Sciences Zoologique. T.138. P.91-114.

Gillies M.T. 1960. A new genus of Tricorythidae (Ephemeroptera) from East Africa // Proceedings of the Royal Entomological Society of London. Ser.B. Vol.29. No.3-4. P.35-40.

Jacobus L.M. \& McCafferty W.P. 2006. Phylogenetic revision of Ephemerythidae (Ephemeroptera: Pannota) // Transactions of the American Entomological Society. Vol.132. No.1-2. P. 75-79.

Kimmins D.E. 1956. Ephemeroptera from Nyasaland, with description of three new species and some interesting nymphal forms // Annals and Magazine of Natural History. Ser.12 (1955). Vol.8. No.95. P.859-880.

Kluge N.J. 1997. A paradoxical problem in the phylogeny of Furcatergalia (Ephemeroptera) // P. Landolt \& M. Sartori (eds). Ephemeroptera \& Plecoptera. Biology-Ecology-Systematics (Proc. VIII Int. Conf. on Ephemeroptera and XII Int. Symposium on Plecoptera, August 1995, Losanne). Mauron+Tinguely \& Lacht SA, Fribourg/Switzerland. P.520526.

Kluge N.J. 2004. The phylogenetic system of Ephemeroptera. Kluwer Academic Publishers. $456 \mathrm{pp}$.

Kluge N.J. (web publicatoion). Phylogeny of Ephemeroptera. http://www.insecta.bio.pu.ru

Kopelke J.-P. 1980. Morphologische Studien an den Eiern der Eintagsfliegen (Ephemeroptera) aus der Emergenz des zentralafrikanischen Bergbaches Kalengo // Mitteilungen der Schweizerischen Entomologischen Gesellschaft. Bd.53. Nr.2-3. S.297-311.

Kopelke J.-P. 1981. Ephemeroptera (Insecta) aus der Emergenz des zentralafrikanischen Berbaches Kalengo (Zaire). Teil II: Leptophlebiidae, Heptageniidae, Tricorythidae, Caenidae // Mitteilungen der Schweizerischen entomologischen Gesellschaft. Bd.54. S.139-156. 